\title{
Tingkat Pemahaman Siswi SMAN 1 Sindang Indramayu Mengenai Kanker Serviks dan Faktor Penyebabnya
}

\author{
Putri Mega Rahayu1, Oghi Hermawan', Nurin Nadzifatil Fitriyah ${ }^{2 *}$ \\ 1) Program Studi Kedokteran, Fakultas Kedokteran dan Kesehatan, Universitas Muhammadiyah Jakarta, Indonesia \\ 2) Departemen Biologi, Fakultas Kedokteran, UIN Syarif Hidayatullah Jakarta, Indonesia \\ *Corresponding author: nurin.n.fitriyah@uin.jkt.ac.id
}

\begin{abstract}
Background: according to data from the Indonesian Ministry of Health, cervical cancer is a cancer with the second highest incidence rate in Indonesia. The large number of cases of cervical cancer that is found, prompts the question, how big is the understanding of the public, especially adolescents, about cervical cancer. Purposes: knowing how the level of understanding of SMAN 1 Sindang Indramayu students regarding cervical cancer and the factors that cause it. Methods: This research method is descriptive by means of data collection by using online questionnaires. Result: It is known that the level of understanding of SMAN 1 Sindang Indramayu students is sufficient. Conclusion: follow up is needed to overcome this.
\end{abstract}

Keywords: causative factors, cervical cancer, understanding

\begin{abstract}
ABSTRAK
Latar Belakang: Kanker serviks merupakan kanker dengan angka kejadian tertinggi ke-2 di Indonesia. Besarnya kasus kanker serviks yang ditemukan, mendorong pertanyaan, seberapa besar pemahaman masyarakat, terutama remaja mengenai kanker serviks. Tujuan: Mengetahui bagaimana tingkat pemahaman siswi SMAN 1 Sindang Indramayu mengenai kanker serviks dan faktor yang menyebabkannya. Metode: Penelitian ini menggunakan metode deskriptif dengan cara pengambilan data secara kuesioner online. Pengambilan data dilakukan pada bulan November- Desember tahun 2020, dengan jumlah sampel sebanyak 85 siswi. Hasil: Berdasarkan hasil penelitian, diketahui bahwa tingkat pemahaman siswi SMAN 1 Sindang Indramayu adalah cukup. Kesimpulan: Diperlukan tindak lanjut untuk mengatasi hal tersebut.
\end{abstract}

Kata kunci: faktor penyebab, kanker serviks, pemahaman

\section{PENDAHULUAN}

Suatu keadaan dimana sel tidak tumbuh secara normal, disebut sebagai kanker $(1,2)$. Kanker merupakan salah satu NonCommunicable Disease atau kelompok penyakit yang tidak menular $(3,4)$.

Ada beberapa jenis kanker, salah satunya adalah kanker serviks. Kanker yang tumbuh pada leher rahim seorang wanita disebut kanker serviks. Berdasarkan studi, ada beberapa penyebab tumbuhnya kanker serviks, diantaranya infeksi Human Papillomavirus (HPV), Virus HPV akan menginfeksi bagian sel kulit dan sel membran mukosa pada leher Rahim (5-7). Tumbuhnya sel kanker, akan berpengaruh 
terhadap kesehatan reproduksi perempuan.

Kesehatan reproduksi perempuan meliputi keadaan sejahtera secara sosial, fisik, dan psikis dalam semua hal yang berhubungan dengan sistem reproduksi (8). Untuk menghindari bahaya yang ditimbulkan, maka seorang perempuan harus bersungguh sungguh dalam menjaga kesehatan reproduksinya $(9,10)$. Berdasarkan data yang diperoleh dari Kementrian Kesehatan Republik Indonesia (Kemenkes RI), angka insiden kanker serviks di Indonesia sebesar 12,70\% dan berada pada urutan ke-2 dari 10 jenis kanker terbanyak (11).

Besarnya kasus kanker serviks yang ditemukan, mendorong pertanyaan, seberapa besar pemahaman masyarakat, terutama remaja mengenai kanker serviks. Berdasarkan penelitian yang dilakukan oleh Surayya Ardillah tahun 2014 mengenai pengetahuan kanker serviks di SMA Negeri 2 Bangkinang Riau, diketahui bahwa dari 90 responden remaja putri di SMA itu, hanya 52 responden $(57,8 \%)$ yang memiliki pengetahuan tinggi, sedangkan 38 responden $(42,2 \%)$ yang memiliki pengetahuan rendah (12).

Apabila dilihat dari penelitian tersebut, dapat dikatakan bahwa sebagian besar remaja putri di Indonesia masih kurang paham mengenai informasi kanker serviks. Oleh karena itu, dilakukan penelitian di SMAN 1 Sindang Indramayu, untuk mengetahui bagaimana tingkat pemahaman siswi SMAN 1 Sindang Indramayu mengenai kanker serviks dan faktor yang menyebabkannya.

\section{METODE}

Penelitian ini merupakan penelitian deskriptif. Penelitian dilakukan dengan cara membagikan kuesioner secara online kepada responden. Sedangkan proses pengambilan data dilakukan dengan cara potong lintang (cross sectional).
Penelitian telah dilakukan di SMAN 1 Sindang Indramayu pada bulan November sampai dengan Desember 2020. Sebelumnya, penelitian ini telah mendapat persetujuan etik dari komisi etik Fakultas Kedokteran dan Kesehatan Universitas Muhammadiyah Jakarta nomor 148/PE/KE/FKK-UMJ/XI/2020. Populasi pada penelitian ini adalah semua siswi kelas XII SMA Negeri 1 Sindang Indramayu pada tahun 2020, yaitu berjumlah 85 orang. Instrumen penelitian yang dipergunakan dalam penelitian ini sudah tervalidasi pada penelitian sebelumnya (12).

Penelitian ini menggunakan data primer melalui kuesioner yang dibagikan ke responden. Data yang telah diperoleh kemudian diolah dengan menggunakan program statistik. Analisis data yang digunakan adalah Analisis Univariat.

Variabel pada penelitian ini yaitu pengetahuan tentang kanker serviks dan pengetahuan tentang pencegahan kanker serviks. Pengetahuan tentang kanker serviks yaitu mengukur pemahaman atau segala hal yang responden ketahui tentang kanker serviks, dalam hal ini adalah mengenai pengertian, penyebab, sifat, dan sampai penularan penyakit dengan kategori baik, cukup dan kurang. Pengetahuan tentang pencegahan kanker serviks yaitu mengukur pemahaman atau segala hal yang responden ketahui tentang pencegahan kanker serviks, dalam hal ini adalah vaksin HPV dan gaya hidup pemicu kanker serviks. Kategori baik apabila subjek menjawab $\geq 75 \%$, cukup apabila subjek menjawab 56-74\% dan kurang apabila subjek menjawab $<55 \%$ dari seluruh pertanyaan dengan benar. 
HASIL

\section{Pengetahuan Tentang Kanker Leher Rahim}

Berdasarkan data yang diperoleh dari penelitian ini, didapatkan data seperti yang tercantum dalam tabel 1 .

Tabel 1. Pengetahuan Responden

\begin{tabular}{|c|c|c|}
\hline Kategori & Frekuensi & Persentase \\
\hline \multicolumn{3}{|c|}{ Kanker Leher Rahim } \\
\hline Baik & 63 & 74.1 \\
\hline Cukup & 19 & 22.4 \\
\hline Kurang & 3 & 3.5 \\
\hline Total & 85 & 100.0 \\
\hline \multicolumn{3}{|c|}{ Vaksin Human Papillomavirus } \\
\hline Baik & 14 & 16.5 \\
\hline Cukup & 32 & 37.6 \\
\hline Kurang & 39 & 45.9 \\
\hline Total & 85 & 100.0 \\
\hline \multicolumn{3}{|c|}{ Gaya Hidup Pemicu Terjadinya Kanker } \\
\hline \multicolumn{3}{|l|}{ Leher Rahim } \\
\hline Baik & 58 & 68.2 \\
\hline Cukup & 24 & 28.2 \\
\hline Kurang & 3 & 3.5 \\
\hline Total & 85 & 100.0 \\
\hline \multicolumn{3}{|c|}{ Pengetahuan secara Umum Tentang } \\
\hline Kanker Servi & & \\
\hline Baik & 36 & 42.4 \\
\hline Cukup & 46 & 54.1 \\
\hline Kurang & 3 & 3.5 \\
\hline Total & 85 & 100.0 \\
\hline
\end{tabular}

Berdasarkan data tabel 1, dari 85 siswi SMA Negeri 1 Sindang, sebagian besar siswi memiliki pengetahuan yang baik mengenai kanker serviks, yaitu sebesar $74,1 \%$. Sebagian besar siswi memiliki pengetahuan yang kurang mengenai Vaksin Human Papillomavirus, yaitu sebesar 45,9\%. Sebagian besar siswi memiliki pengetahuan yang baik mengenai gaya hidup yang menjadi pemicu terjadinya kanker leher Rahim, yaitu sebesar 68,2\%. Pada variabel pengetahuan, sebagian besar siswi memiliki pengetahuan secara umum yang cukup mengenai kanker serviks, yaitu sebesar $54,1 \%$.

\section{PEMBAHASAN}

Kanker serviks atau kanker leher rahim merupakan salah satu penyakit keganasan atau neoplasma yang terjadi di bagian terendah dari rahim yang menonjol ke puncak liang senggama (vagina) yaitu bagian leher atau mulut rahim. Penyebab utama dari kanker jenis ini adalah infeksi Human Papillomavirus $(2,13,14)$.

Kanker serviks adalah salah satu kanker yang paling sering menyerang wanita di seluruh dunia. Infeksi Human Papilomavirus (HPV) adalah penyebab utama kanker serviks (15). Vaksinasi dan skrining Pap smear adalah yang terbaik metode pencegahan penyakit (16-19).

Di banyak negara dengan sumber daya rendah seperti di Amerika Selatan dan Tengah, Afrika Sub-Sahara, dan di bagian Asia Selatan serta Asia Tenggara kanker serviks terus menjadi ancaman kesehatan masyarakat yang utama dan masih menjadi kanker terdepan, khususnya bagi wanita (20). Oleh karenanya, peningkatan pengetahuan mengenai kanker serviks harus menjadi fokus tersendiri. Agar angka infeksi dapat lebih terkendali (21-23).

Penelitian terdahulu, yang telah dilakukan oleh Surayya Ardillah (2015) mengenai pengetahuan secara umum tentang kanker serviks. Dalam penelitian ini dilakukan penilaian kepada 90 responden dengan analisis univariat. Hasil penelitian ini menunjukkan bahwa sebanyak 38 responden $(42.2 \%)$ dengan pengetahuan yang dimilikinya rendah dan sebanyak 52 responden $(57,8 \%)$ dengan pengetahuan yang dimilikinya tinggi (12).

Rashwan et al pada tahun 2009 juga melakukan penelitian mengenai pengetahuan tentang kanker serviks di Kuala Lumpur Malaysia. Penelitian dilakukan dari bulan April 2009 sampai dengan bulan September 
2009 di 8 sekolah di wilayah Kuala Lumpur dengan menggunakan kuesioner yang telah diuji sebelumnya dan divalidasi. Hasil penelitian menunjukkan bahwa responden memiliki pengetahuan kanker serviks dan pencegahannya yang rendah meskipun sebagian besar pelajar $(80,4 \%)$ pernah mendengar tentang penyakit tersebut. Tingkat pengetahuan tentang kanker serviks dan pencegahannya secara signifikan lebih tinggi di antara siswa dari jurusan sains $(p<0,001)$ dibandingkan dengan siswa dari aliran seni. Kesimpulan dari penelitian ini, sebagian besar siswa memiliki pengetahuan yang rendah tentang kanker serviks dan pencegahannya (16).

Berdasarkan hasil penelitian ini, sebagian besar siswa $(54,2 \%)$ mempunyai pengetahuan cukup tentang kanker serviks. Pengetahuan yang cukup tentang kanker serviks pada remaja putri dapat disebabkan oleh faktor-faktor yang mempengaruhi salah satunya adalah kurangnya atau terbatasnya informasi yang didapatkan oleh responden tentang kanker serviks. Dengan didapatkannya informasi baru oleh responden, maka pengetahuan tersebut juga dapat bertambah.

Hal ini sejalan dengan penelitian yang dilakukan oleh Miftakhul Jannah pada tahun 2011, dalam penelitiannya didapatkan sebagian besar yaitu sekitar 68,2\% responden memiliki pengetahuan yang cukup tentang kanker serviks dan salah satu faktornya adalah kurangnya informasi (24). Namun berbeda halnya dengan penelitian yang dilakukan oleh Sylvana pada tahun 2012, dalam penelitiannya didapatkan sebagian besar yaitu sekitar $87 \%$ responden memiliki pengetahuan yang rendah tentang kanker serviks (25), serta penelitian Rashwan tahun 2009 yang menyebutkan bahwa responden memiliki pengetahuan yang rendah mengenai kanker serviks dan pencegahannya. Perbedaan hasil penelitian dimungkinkan dipengaruhi oleh lingkungan masing-masing responden itu sendiri, serta tersedianya fasilitas untuk mengakses berbagai informasi, termasuk informasi mengenai kesehatan reproduksi.

\section{SIMPULAN}

Berdasarkan hasil penelitian, diketahui bahwa tingkat pengetahuan siswa putri SMAN 1 Sindang, Indramayu, Jawa Barat, mengenai kanker serviks adalah cukup. Setelah diketahuinya bahwa pengetahuan mengenai kanker serviks pada siswa putri SMAN 1 Sindang sebagian besar dalam kategori cukup, maka diperlukan tindak lanjut untuk meningkatkan tingkat pengetahuan mengenai kanker serviks.

\section{UCAPAN TERIMA KASIH}

Terimakasih penulis ucapkan kepada seluruh warga SMAN 1 Sindang, kepada para responden, serta stakeholder yang telah membantu berjalannya penelitian ini.

\section{KONFLIK KEPENTINGAN}

Peneliti tidak memiliki konflik kepentingan, dan tidak ada afiliasi atau koneksi dengan entitas atau organisasi apa pun, yang dapat menimbulkan pertanyaan bias dalam diskusi dan kesimpulan naskah.

\section{REFERENSI}

1. Amin TM, Maelani A. Kebersihan Alat Vital Wanita Sebagai Pencegah. J Inov dan Kewirausahaan. 2014;3(1):28-31.

2. Cohen PA, Jhingran A, Oaknin A, Denny L. Cervical cancer. Lancet. 2019;393(10167):169-82.

3. Evriarti PR, Yasmon A. Patogenesis Human Papillomavirus (HPV) pada Kanker Serviks. J Biotek Medisiana Indones. 2019;8(1):23-32.

4. Small W, Bacon MA, Bajaj A, 
Chuang LT, Fisher BJ, Harkenrider MM, et al. Cervical cancer: A global health crisis. Cancer. 2017;123(13):2404-12.

5. Lowy DR, Schiller JT. Reducing HPV-associated cancer globally. Cancer Prev Res. 2012;5(1):18-23.

6. Araldi RP, Sant'Ana TA, Módolo DG, de Melo TC, Spadacci-Morena DD, de Cassia Stocco R, et al. The human papillomavirus (HPV)related cancer biology: An overview. Biomed Pharmacother. 2018;106(June):1537-56.

7. Crosbie EJ, Einstein MH, Franceschi S, Kitchener HC. Human papillomavirus and cervical cancer. Lancet. 2013;382(9895):889-99.

8. Caserta D, Mantovani A, Marci R, Fazi A, Ciardo F, La Rocca C, et al. Environment and women's reproductive health. Hum Reprod Update. 2011;17(3):418-33.

9. Morris JL, Rushwan H. Adolescent sexual and reproductive health: The global challenges. Int J Gynecol Obstet. 2015;131:S40-2.

10. Kamzol W, Jaglarz K, Tomaszewski KA, Puskulluoglu M, Krzemieniecki K. Assessment of knowledge about cervical cancer and its prevention among female students aged 17-26 years. Eur J Obstet Gynecol Reprod Biol. 2013;166(2):196-203.

11. RI KK. Pedoman Nasional Pelayanan Kedokteran Tata Laksana Kanker Serviks. 2018.

12. Ardillah S. Gambaran Pengetahuan Remaja Puteri Tentang Kanker Serviks Di SMA Negeri 2 Bangkinang Riau. Univ Muhammadiyah Jakarta. 2014;

13. Fitrisia CA et al. Analisis Faktorfaktor yang Berhubungan dengan
Kejadian Lesi Pra Kanker Serviks pada Wanita Pasangan Usia Subur di Wilayah Kerja Puskesmas Muara Bungo 1. J Kesehat Andalas. 2020;8(4):33-43.

14. Castellsague X, Bruni L, Alemany L, Diaz M, De Sanjosé S, Bosch FX. The epidemiology of cervical cancer. HPV Cerv Cancer Achiev Prev Futur Prospect. 2012;9781461419:63-83.

15. Tonguc E, Gungor T, Var T, Kavak E, Yucel M, Uzunlar O. Knowledge about HPV, relation between HPV and cervix cancer and acceptance of HPV vaccine in women in eastern region of Turkey. J Gynecol Oncol. 2012;24(1):7-13.

16. Rashwan H, Ishak I, Sawalludin N. Knowledge and views of secondary school students in kuala lumpur on cervical cancer and its prevention. Asian Pacific J Cancer Prev. 2013;14(4):2545-9.

17. Assoumou SZ, Mabika BM, Mbiguino AN, Mouallif M, Khattabi A, Ennaji MM. Awareness and knowledge regarding of cervical cancer, Pap smear screening and human papillomavirus infection in Gabonese women. BMC Womens Health. 2015;15(1):1-7.

18. Lei J, Ploner A, Elfström KM, Wang J, Roth A, Fang F, et al. HPV Vaccination and the Risk of Invasive Cervical Cancer. N Engl J Med. 2020;383(14):1340-8.

19. Kessler TA. Cervical Cancer: Prevention and Early Detection. Semin Oncol Nurs. 2017;33(2):17283.

20. Daniyal M, Akhtar N, Ahmad S, Fatima U, Akram M, Asif HM. Update knowledge on cervical cancer incidence and prevalence in 
Asia. Asian Pacific J Cancer Prev. 2015;16(9):3617-20.

21. Basu P, Mittal S, Bhadra Vale D, Chami Kharaji Y. Secondary prevention of cervical cancer. Best Pract Res Clin Obstet Gynaecol. 2018;47:73-85.

22. Urasa M, Darj E. Knowledge of cervical cancer and screening practices of nurses at a regional hospital in Tanzania. Afr Health Sci. 2011;11(1):48-57.

23. Lyimo FS, Beran TN. Demographic, knowledge, attitudinal, and accessibility factors associated with uptake of cervical cancer screening among women in a rural district of Tanzania: Three public policy implications. BMC Public Health. 2012;12(1):22.

24. Miftakhul Jannah R. Gambaran Tingkat Pengetahuan Remaja Putri Tentang Kanker Serviks Di MAN Sidoarjo. 2011.

25. Sylvana. Gambaran Tingkat Pengetahuan dan Perilaku Pencegahan Kanker Serviks Pada Mahasiswi S1 Reguler Fakultas Psikologi Universitas Indonesia Tahun 2012. Universitas Indonesia; 2012. 